H. GUO,* H. LIU, F.-L. ZHU, R. NA, H. JIANG, Y. WU, L. ZHANG, Z. LI, H. YU, B. WANG, Y. XIAO, X.-P. HU, * M. WANG (CHINA AGRICULTURAL UNIVERSITY, BEIJING AND DALIAN INSTITUTE OF CHEMICAL PHYSICS, P. R. OF CHINA)

Enantioselective Copper-Catalyzed [3+3] Cycloaddition of Azomethine Ylides with Azomethine Imines Angew. Chem. Int. Ed. 2013, 52, 12641-12645.

\title{
[3+3] Cycloaddition of Azomethine Ylides with Azomethine Imines
}

\section{Category}

Metal-Catalyzed Asymmetric

Synthesis and

Stereoselective

Reactions

\section{Key words}

azomethine ylides

azomethine imines

copper

SYNFACDuth
of the mont

$$
\begin{aligned}
& \mathrm{R}^{1}=\mathrm{CO}_{2} \mathrm{Et} \\
& + \\
& \mathrm{N}_{-}^{+}=\mathrm{N}^{\mathrm{N}^{2}}
\end{aligned}
$$

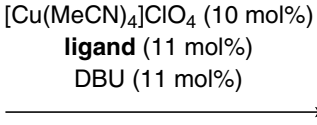

$\mathrm{CH}_{2} \mathrm{Cl}_{2}(0.1 \mathrm{M}),-5^{\circ} \mathrm{C}, 24 \mathrm{~h}$

Selected examples:

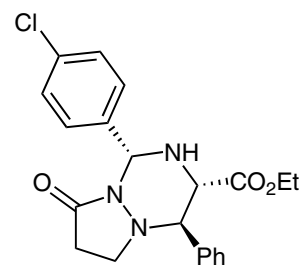

$86 \%$ yield
$96 \%$ ee $96 \%$ ee
$d r>20: 1$

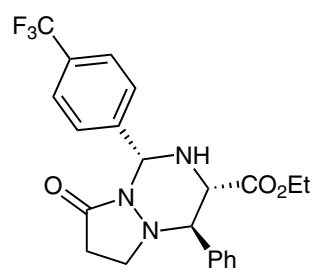

$89 \%$ yield $95 \%$ ee $d r>20: 1$<smiles>CCCC1C(OCC)NC([Tl])N2CCC(=O)N12</smiles>

up to $89 \%$ yield up to $96 \%$ ee up to $>20: 1 \mathrm{dr}$ $0.3 \mathrm{mmol}$ scale 24 examples

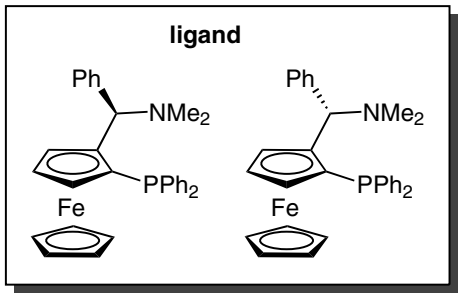<smiles>CCOC(=O)C1NC(c2ccccc2)N2CCC(=O)N2C1c1ccccc1Br</smiles>

$77 \%$ yield $91 \%$ ee $\mathrm{dr}=2: 1$<smiles>CCOC(=O)C1N[C@@H](c2ccccc2)N2CCC(=O)N2[C@H]1c1cccc(Br)c1</smiles>

$76 \%$ yield $90 \%$ ee $d r>20: 1$

Product derivatization:<smiles>c1ccc(C2NN3CCCOCC2NC3c2ccccc2)cc1</smiles>

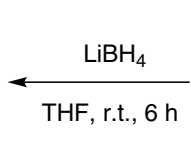

$31 \%$ yield racemic<smiles>CCOC(=O)C1N[C@@H](c2ccccc2)N2CCC(=O)N12</smiles>

$95 \%$ ee

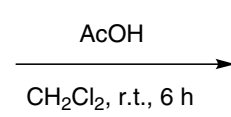<smiles>CCOC(=O)[C@@H]1N[C@@H](c2ccccc2)[C@@H](c2ccccc2)N2CCC(=O)N12</smiles>

$95 \%$ yield $85 \%$ ee
Significance: With the use of a [3+3] cycloaddition the authors were able to generate biologically active hexahydro-8H-pyrazolo[1,2-a][1,2,4]triazin8-one derivatives. In a highly diastereo- and enantioselective manner, azomethine ylides were reacted with azomethine imines in the presence of copper and ferrocenyl chiral P,N-ligands.
Comment: [3+3] And [3+4] cycloadditions with azomethine ylides are not as well known as their $[3+2]$ counterparts. Pioneering work in the use of 1,3-dipolar [3+2] cycloadditions with azomethine ylides was made by the groups of Jørgensen (Angew. Chem. Int. Ed. 2002, 41, 4236) and Zhang (J. Am. Chem. Soc. 2002, 124, 13400). In the presence of $\mathrm{LiBH}_{4}$ the product of the [3+3] adduct rearranged to an unexpected compound. This interesting molecule was formed as a single diastereomer, but was found to be racemic.

SYNFACTS Contributors: Mark Lautens, Zafar Qureshi

DOI: 10.1055/s-0033-1340590; Reg-No.: L17313SF 